\title{
ROTATION OF THE EARTH
}

Edited by P. MELCHIOR and S. YUMI
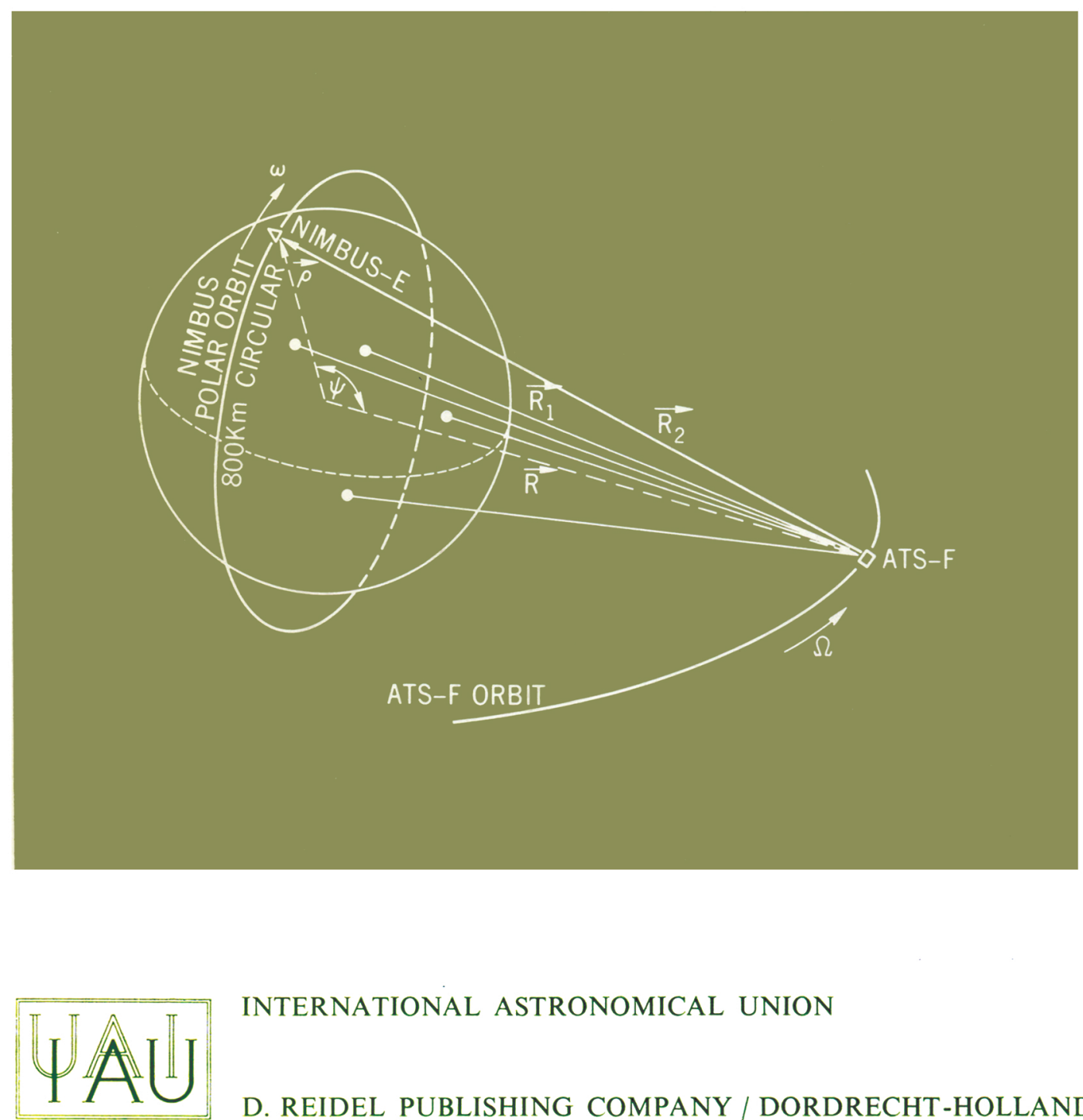

INTERNATIONAL ASTRONOMICAL UNION

D. REIDEL PUBLISHING COMPANY / DORDRECHT-HOLLAND https://doi.org/10.1017/S007418090009851X Published online by Cambridge University Press 
SYMPOSIUM No. 48

The present volume covers the Proceedings of I.A.U. Symposium No. 48 on the Rotation of the Earth, held in Morioka, Japan, May 9-15, 1971.

Among the subjects dealt with are: coordinates of the pole in a uniform system; comparison of the coordinates of the pole by time observation with those by latitude observation; analyses of polar motion and its interpretation; the theory of polar motion and rotation of the Earth; geodynamics; geopotential; crustal movement; and new techniques and instruments such as the laser, radar, Doppler observation of satellites, VLBI, etc.

The Symposium urged the furthering of geodynamical studies and the development of new techniques such as laser measurements of distances to the Moon or artificial satellites, Doppler observation, VLBI, etc., for the determination of polar motion and the rotation of the Earth in addition to the optical instruments which have been used up to now. 
SYMPOSIUM No. 41

NEW TECHNIQUES

IN SPACE ASTRONOMY

SYMPOSIUM No. 42

WHITE DWARFS

SYMPOSIUM No. 43

SOLAR MAGNETIC FIELDS

SYMPOSIUM No. 44

EXTERNAL GALAXIES

AND QUASI STELLAR

OBJECTS

SYMPOSIUM No. 45

THE MOTION,

EVOLUTION OF ORBITS,

AND ORIGIN OF COMETS

SYMPOSIUM No. 46

THE CRAB NEBULA

SYMPOSIUM No. 47

THE MOON

D. REIDEL PUBLISHING COMPANY

DORDRECHT-HOLLAND 
ROTATION OF THE EARTH

https://doi.org/10.1017/S007418090009851X Published online by Cambridge University Press 
INTERNATIONAL ASTRONOMICAL UNION

UNION ASTRONOMIQUE INTERNATIONALE

SYMPOSIUM No. 48

HELD IN MORIOKA, JAPAN, 9-15 MAY 1971

\title{
ROTATION OF THE EARTH
}

\author{
EDITED BY \\ PAUL MELCHIOR \\ Observatoire Royal de Belgique, Université de Louvain, Belgique \\ AND \\ SHIGERU YUMI \\ International Latitude Observatory, Mizusawa-Shi, Iwate-Ken, Japan \\ WITH THE COOPERATION OF \\ LADY JEFFREYS
}

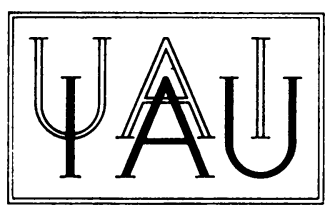

D. REIDEL PUBLISHING COMPANY

DORDRECHT-HOLLAND

1972 


\author{
Published on behalf of \\ the International Astronomical Union \\ by \\ D. Reidel Publishing Company, Dordrecht, Holland
}

All Rights Reserved

Copyright (c) 1972 by the International Astronomical Union

Library of Congress Catalog Card Number 70-188004

ISBN $902770242 X$

No part of this book may be reproduced in any form, by print, photoprint, microfilm, or any other means, without written permission from the publisher

Printed in The Netherlands by D. Reidel, Dordrecht 


\section{TABLE OF CONTENTS}

PREFACE

INTRODUCTION: PAUl MELChIOR / Past and Future of Research Methods in Problems of the Earth's Rotation (Presidential Address)

XI

1. HAROLD JEFFREYS / Creep in the Earth and Planets (Invited Lecture)

2. RAIMUNDO O. VICENTE and SHIGERU YUMI / Revised Values (1941-1961) of the Coordinates of the Pole Referred to the CIO

3. E. P. FEDOROV, A. A. RORSUN, S. P. MAJOR, N. T. PANCHENKO, V. K. TARADY, and YA. A. YATSKIV / New Determination of the Polar Motion from 1890 to 1969

4. P. MELCHIOR, R. DEJAIFFE, and R. VERBEIREN / General Considerations about the Revision of All the Calculations of the International Latitude Service

5. E. M. GAPOSCHKIN / Analysis of Pole Position from 1846 to 1970

6. G. P. H. PEDERSEN and M. G. ROCHESTER / Spectral Analyses of the Chandler Wobble

7. HAROLD JEFFREYS / The Variation of Latitude

8. E. Proverbio, F. CARTA, and F. MAZzoleni / Analysis of the Chandler Period of Polar Coordinates Calculated by the Orlov Method

9. BERNARD GUINOT / Comments on the Changes in Amplitude of the Chandlerian Wobble

10. TOYOZO OKUDA / An Interpretation of the Ambiguity between Annual Terms Obtained by Time and Latitude Observations

11. SÊICHI OKAZAKI and MITSUKO NASAKA / Comparisons between Results of Polar Coordinates Derived from Time Data and Those from Latitude Ones

12. Shigetaka iljima and SêIChI okazaki / On the Short Period Terms in the UT1 and Those in the Polar Motion

13. H. J. A BR A HAM / On the Regularity of Fluctuations in Annual and Secular Polar Motions

14. IVAN I. MUELler and C. R. SCHWARZ / Separating the Secular Motion of the Pole from Continental Drift - Where and What to Observe?

15. E. P. FEDOROV, A. A. KORSUN, and N. T. MIRONOV / Non-Periodic Latitude Variations and the Secular Motion of the Earth's Pole

16. DENNIS D. MCCARTHY / Secular and Nonpolar Variation of Washington Latitude

17. e. Proverbio, F. CARTA, and F. MAZzoleni / Secular and Long-Term Variations of the Polar Motion 
18. R. J. ANDERLE / Accuracy of Doppler Determinations of Station Positions 101

19. M. FEISSEL, B. GUINOT, and N. TATON / Comparison of the Coordinates of the Pole as Obtained by Classical Astrometry (IPMS, BIH) and as Obtained by Doppler Measurements on Artificial Satellites (Dahlgren Polar Monitoring Service)

20. F. O. VON BUN / The ATS-F/NIMBUS-E Tracking Experiment

21. DAVID E. SMITH, PETER J. DUNN, and RONALD KOLENKIEWICZ / A Laser Polar Motion Experiment

22. KURT LAMBECK / Polar Motion from the Tracking of Close Earth Satellites

23. E. M. GA POSChKIN / Pole Position Studied with Artificial Earth Satellites

24. CARol A. Williams / Corrections to Star Catalogues from Satellite Observations

25. R. O. Vicente / Old and New Methods of Observing Polar Motion

26. DON R. MONGER / Some Results from the Automatic PZT at Richmond, Florida

27. F. NOËL / Seasonal Effects Observed in Time Determinations at Santiago

28. G. TELEKI / The Use of the Refractional Pair Observations

29. G. TELEKI and B. ŠEVARLIĆ / On the Determination of Anomalous Refraction out of Astrometrical Measurements in the Zenith Zone

30. IETSUNE TSUboKAWA and ShUNRo hokUgo / On the Automatic Electronic Astrolabe

31. R. R. NEWTON / Historic Variations in the Rotation of the Earth

32. WM. MARKOWITZ / Rotational Accelerations

33. G. E. O. GIACAGLIA / Random Variations in the Earth Rotation

34. B. D. TAPLEY and B. E. SCHUTZ / Estimation of Random Changes in the Earth's Rotation

35. J. A. JасовS / Possible Changes in the Core-Mantle and Inner-Outer Core Boundaries

36. YOShIO KUBo / An Explanation of the Polar Motion by a Rigid Core-Mantle Model

37. JOSE MATEO / Motion of the Core, and Its Influence on the Earth's Axis

38. YASUJIRO WAKo / Kimura's Z-Term and the Liquid Core Theory

39. CHUichi KAKUTA and SHINko AOKI / The Excess Secular Change in the Obliquity of the Ecliptic and Its Relation to the Internal Motion of the Earth

40. WALTER FRICKE / On the Motion of the Equator and the Ecliptic

41. SUZA N NE DÉBAR B AT / Nearly Diurnal Nutation Derived from the Observations of Time and Latitude

42. YA. S. YATSKIV / On the Comparison of Diurnal Nutation Derived from Separate Series of Latitude and Time Observations 
45. MiChAEL A. CHINNERY and FRED J. Wells / On the Correlation between Earthquake Occurrence and Disturbances in the Path of the Rotation Pole

46. NAOSUKE SEKIGUCHI / On Some Natures of the Excitation and Damping of the Polar Motion

47. KUNIHIKO SHIMAZAKI and HitOSHI TAKEUCHI/Excitation of the Chandler Wobble by Large Earthquakes

48. TAKESI YUKUTAKE / Effect of the Change in the Geomagnetic Dipole Moment on the Rate of the Earth's Rotation

49. CHIKARA SUGAWA, CHUICHI KAKUTA, and HideO MATSUKURA / On the Relation between the Rotation of the Earth and Solar Activity

50. N. N. PARIISKY and B. P. PERTSEV / The Determination of Love's Number $K$ from Tidal Variations of Rotation of a Compressible Earth

51. P. BROSCHE and J. SÜNDERMANN / On the Torques Due to Tidal Friction of the Oceans and Adjacent Seas

52. N. N. PARIISKY, M. V. KUZNETSOV, and L. V. KUZNETSOVA / On the Effect of Ocean Tides on the Secular Retardation of the Earth's Rotation 